\title{
PENULISAN MAKALAH MAHASISWA PADA MKU BAHASA INDONESIA DENGAN METODE MIND MAPPING
}

\author{
Oleh: Dian Nuzulia Armariena \\ (Dosen Universitas PGRI Palembang) \\ Email:dianarera@yahoo.com
}

\begin{abstract}
Abstrak
Keterampilan menulis adalah kemampuan berbahasa yang kompleks. Kebanyakan orang mengalami kesulitan dalam menguasai keterampilan menulis. Penelitian ini dimaksudkan untuk mengembangkan kemampuan menulis makalah yang dirancang melalui rencana pembelajaran dengan melibatkan mahasiswa dengan metode mind mapping. Metode yang digunakan adalah metode eksperimen. Berdasarkan hasil penelitian yang telah dilakukan dapat disimpulkan bahwa berdasarkan analisis data untuk menguji hipotesis dengan menggunakan uji-t diperoleh hasil menunjukkan bahwa $t_{\text {hitung }}=3,27$ dimana $t_{\text {hitung }}$ lebih besar daripada $t_{\text {tabel }}=1,67$, maka dapat disimpulkan ada pengaruh model pembelajaran mind mapping terhadap keterampilan menulis makalah pada MKU Bahasa Indonesia.
\end{abstract}

Kata Kunci: Penulisan Makalah, Bahasa Indonesia, Mind Mapping

\section{WRITING OF STUDENT PAPERS IN INDONESIAN LANGUAGE USING THE MIND MAPPING METHOD}

\begin{abstract}
Writing skills are complex language skills. Most people have difficulty mastering writing skills. This research is intended to develop the ability to write papers designed through learning plans by involving students with mind mapping methods. The method used is an experimental method. Based on the results of the research that has been done it can be concluded that based on data analysis to test the hypothesis using the t-test the results show that $t_{\text {count }}=3.27$ where tcount is greater than $t_{\text {table }}=1.67$, it can be concluded there is an influence of mind mapping learning model on paper writing skills at MKU Indonesian language.
\end{abstract}

Keywords: Paper Writing, Indonesian Language, Mind Mapping 


\section{A. PENDAhuluan}

Menulis merupakan keterampilan yang harus dikuasai oleh setiap mahasiswa dalam mengikuti perkuliahan. Menulis adalah sesuatu kegiatan menuangkan pikiran, gagasan, dan perasaan ke dalam bentuk tulisan. kegiatan menulis membantu mahasiswa menuangkan pikiran secara ilmiah dengan menghasilkan sebuah karya ilmiah, yaitu makalah. Menulis makalah tidak secara otomatis bisa dilakukan oleh mahasiswa melainkan dengan latihan dan praktik yang dilakukan dalam menulis makalah.

Menulis dianggap sebagai keterampilan tersulit karena menuangkan pikiran menjadi tulisan adalah kegiatan yang tidak mudah dilakukan. Menulis merupakan aktivitas memindahkan bentuk lisan ke dalam bentuk tulisan. Orang yang terampil berbicara seperti berpidato maupun berceramah, belum tentu memiliki kemahiran yang sama ketika ia menuangkan pidato atau ceramahnya dalam bentuk tulisan. Hal ini disebabkan bahasa tulis dengan bahasa lisan memiliki perbedaan.

Dalam kegiatan menulis, seorang penulis harus memiliki kemampuan menggambarkan yang ingin dibicarakannya kepada pembaca. Pilihan kata dan susunan kalimat yang digunakannya harus tepat dan dapat membuat pembacanya ikut membayangkan dan merasakan untuk memahami maksud penulis tersebut (Tarigan, 2008:21-22). Berdasarkan survei yang dilakukan Suparno dan Yunus (2009:1.4), ditemukan bahwa aspek pembelajaran bahasa yang paling tidak disukai oleh mahasiswa adalah menulis. Hal ini disebabkan ketidaktahuan mahasiswa terhadap yang harus ditulisnya sehingga mahasiswa selalu menganggap bahwa menulis adalah pelajaran yang sulit.

Dosen hanya memberikan pokok materi yang harus dituliskan oleh mahasiswa tanpa mengajarkan cara menulis kepada mahasiswa. Berdasarkan pokok materi yang diberikan oleh dosen, mahasiswa harus menulis sebuah makalah Hal inilah yang sulit dilakukan oleh mahasiswa karena membuat makalah membutuhkan kemampuan menentukan pokok materi bahasan.

Kegiatan menulis justru akan membantu seseorang agar dapat berpikir lebih kritis. Kellog (2008:1-2) menjelaskan bahwa belajar menulis teks yang koheren dan 
efektif merupakan suatu pencapaian yang sulit. Hal ini disebabkan literasi merupakan pencapaian budaya yang tidak pernah dipelajari sama sekali. Menulis teks pada tingkat mahir tidak hanya melibatkan sistem bahasa. Hal ini merupakan tantangan tersendiri terhadap sistem kognitif, yaitu memori dan berpikir.

Dalam menulis makalah, penulis memerlukan data dan fakta yang kemudian ditambahkan dengan pendapat penulis tersebut. Proses penulisan ini memerlukan pemikiran kritis penulis tersebut. Oleh karena itu, proses menulis makalah tidak dapat dilepaskan dari keterampilan berpikir kritis dan memori (Armariena, 2015:370).

Dalam pembelajaran di kelas, mahasiswa cenderung kurang mampu membuat makalah dengan benar, mahasiswa lebih cenderung mengulangi kesalahan yang sama, tidak memperhatikan format, dan EYD. Hal ini berdasarkan pengamatan peneliti di kelas, mahasiswa cenderung tidak teliti dalam menyusun makalah. Hal ini disebabkan mahasiswa kesulitan menulis makalah.

Untuk mengatasi masalah tersebut, model pembelajaran yang sebaiknya digunakan harus dapat membantu mahasiswa menulis makalah yaitu model pembelajaran mind mapping. Hal ini sejalan dengan pendapat Armariena (2017:371) menyatakan bahwa proses menulis terutama menulis makalah memerlukan metode yang tepat sehingga memudahkan mahasiswa mengeluarkan pendapat, membuat urutan ide pokok dengan tepat serta menghasilkan makalah yang lengkap.

Penggunaan mind mapping atau peta pikiran mahasiswa untuk memetakan semua pengetahuan yang dimiliki pada waktu menulis karangan ilmiah, dengan cara itu mahasiswa akan terbantu untuk menulis makalah dengan mudah. Mind mapping (peta pikiran) merupakan salah satu cara termudah untuk menempatkan informasi ke dalam otak dan mengambil informasi ke luar dari otak. Mind mapping/peta pikiran dapat membantu mahasiswa belajar menyusun dan menyimpan sebanyak mungkin informasi yang diinginkan dan cara mengelompokkannya dilakukan secara alami, yaitu dengan memberi akses yang mudah dan langsung terhadap sesuatu yang diinginkan.

Dengan berbagai kelebihan, mind mapping (peta pikiran) diprediksi dapat 
mempermudah mahasiswa dalam menulis karangan makalah secara sistematis. Sehingga penggunaan mind mapping (peta pikiran) diharapkan dapat memberikan bantuan kepada siswa dalam meningkatkan keterampilan menulis makalah.

Berdasarkan latar belakang, masalah penelitian ini dapat dirumuskan sebagai adalah apakah terdapat pengaruh penggunaan model pembelajaran mind mapping terhadap kemampuan menulis makalah pada MKU Bahasa Indonesia. Secara umum, penelitian ini bertujuan untuk mengetahui dan memperoleh gambaran terhadap pengaruh penggunaan model pembelajaran mind mapping terhadap kemampuan menulis makalah pada MKU Bahasa Indonesia.

Kemampuan berpikir tidak dapat dilepaskan perannya dari pendidikan, khususnya pendidikan bahasa Indonesia. Dalam materi menulis, misalnya, seorang mahasiswa harus memiliki kemampuan berpikir yang baik dan memori agar dapat menghasilkan makalah yang baik. Dalam menulis sebuah makalah, kemampuan yang dibutuhkan adalah berpikir dan memori.

Alek dan Achmad (2010:112), mengatakan bahwa makalah merupakan karya tulis yang memuat pemikiran tentang suatu masalah atau topik tertentu yang ditulis secara sistematis dan runtun dengan disertai analisis yang logis dan objektif. Keterampilan menulis makalah sangat potensial untuk dimiliki mahasiswa, dalam artinya, seorang mahasiswa diharapkan mampu menulis makalah dalam kegiatan ilmiah di sekolah, baik yang dilakukan dengan penelitian maupun melalui pengamatan/studi pustaka.

Melalui penulisan makalah, mahasiswa bisa mengaplikasikan pikiran-pikiran yang kritis dan analitis ke dalam bentuk tulisan yang sistematis dan ilmiah. Untuk mewujudkan hal tersebut, dibutuhkan pengetahuan tentang unsur-unsur penulisan makalah untuk menuangkan hasil pemikirannya di dalam satu tulisan yang ilmiah. Sebab, makalah yang baik adalah makalah yang berisi unsur-unsur penulisan makalah dan memiliki nilai ilmiah.

\section{B. METODOLOGI PENELITIAN}

Metode yang digunakan dalam penelitian ini adalah metode eksperimen semu. 
Penelitian ini dilakukan untuk memperoleh jawaban dari hipotesis yang telah disusun. Hal ini mengacu pada pendapat Sevilla, dkk. (1993:93) bahwa metode eksperimen adalah metode penelitian yang dapat menguji hipotesis mengenai hubungan sebab-akibat, serta merupakan pendekatan yang paling sahih dalam memecahkan masalah, baik secara praktis maupun secara teori. Pada penelitian eksperimen ini menggunakan desain penelitian one group pretest posttest design.

Instrumen yang digunakan untuk mengumpulkan data kemampuan menulis makalah ini berbentuk tes tertulis, yaitu tes menulis makalah. Mahasiswa diminta menulis sebuah makalah yang telah ditentukan materi pokok bahasan oleh peneliti. Untuk menilai hasil tulisan mahasiswa, penilaian yang dilakukan mengacu pada komponen-komponen dengan menggunakan kriteria yang diadaptasi dari H.L. Jakobs dkk. (1981:29) menyatakan bahwa ada lima aspek yang bisa dijadikan ukuran untuk menilai kemampuan menulis karya ilmiah meliputi: (1) isi, (2) organisasi, (3) kosakata dan istilah, (4) penggunaan bahasa, dan (5) penerapan ejaan dan teknik penulisan.

\section{HASIL PENELITIAN DAN PEMBAHASAN}

\section{Deskripsi Data}

Tes dalam penelitian ini berupa unjuk kerja, yaitu mahasiswa diperintahkan menulis sebuah makalah secara kelompok. Pada tes awal, mahasiswa diminta untuk menulis sebuah makalah sesuai dengan pokok bahasan materi pertemuan." Setiap pertemuan dievaluasi secara bergiliran setiap kelompok.

\section{Uji Normalitas Nilai Menulis Makalah}

Uji normalitas dilakukan pada tes awal. Tes awal kemampuan menulis makalah adalah kemampuan menulis yang dimiliki mahasiswa sebelum proses pembelajaran berlangsung. Kemampuan awal menulis makalah merupakan ratarata dari skor tes unjuk kerja menulis makalah. 
a) Hasil Pretes \& Postes Menulis Makalah

Table 1 Analisis Pretes dan Postes Menulis Makalah Paired Samples Statistics

\begin{tabular}{|c|c|c|c|c|c|}
\hline & Mean & $\mathrm{N}$ & Std. Deviation & $\begin{array}{c}\text { Std. Error } \\
\text { Mean }\end{array}$ \\
\hline Pair 1 & $\begin{array}{l}\text { Postes Kemampuan } \\
\text { Menulis Kelas Eksperimen } \\
\begin{array}{l}\text { Pretes Kemampuan } \\
\text { Menulis Kelas Eksperimen }\end{array}\end{array}$ & 14,75 & 10 & 5,75 & 1,86 \\
\hline
\end{tabular}

Paired Samples Correlations

\begin{tabular}{|cl|c|c|c|}
\hline & & $\mathrm{N}$ & Correlation & Sig. \\
\hline Pair 1 & $\begin{array}{l}\text { Postes Kemampuan Menulis Kelas } \\
\text { Eksperimen \& Pretes Kemampuan } \\
\text { Menulis Kelas Eksperimen }\end{array}$ & 10 & 0,452 & 0,006 \\
\hline
\end{tabular}

Berdasarkan tabel di atas, signifikansi berada pada 0,000. Hal ini menunjukkan bahwa terdapat kenaikan yang signifikan dari kedua data tersebut. Selain itu, terlihat jelas bahwa terdapat peningkatan skor antara tes awal dan tes akhir menulis makalah siswa kelas eksperimen. Skor rata-rata siswa ketika tes awal adalah 7,37, sedangkan ketika tes akhir adalah 14,75 . Selisih antara tes awal dan tes akhir adalah sebesar 7,38 .

\section{Pengujian Hipotesis}

Pengujian hipotesis dilakukan untuk menguji adakah pengaruh model pembelajaran mind mapping dan keterampilan menulis makalah mahasiswa. Hipotesis ini menguji dua sampel secara bersama-sama. Hal yang dilakukan adalah membandingan kemampuan menulis makalah kedua data, yaitu pretest dan posttest.

Jadi $t_{\text {hitung }}$ yang diperoleh dari data yaitu sebesar 3,27 sedangkan $t_{\text {tabel }}$ adalah nilai $t$ yang terdapat pada daftar distribusi $t_{\text {tabel }}$ diperoleh nilai 1,67. Hal ini berarti $t_{\text {hitung }}$ yang besarnya 3,27 lebih besar dari pada $t_{\text {tabel }}$. Dengan demikian sesuai dengan kriteria pengujian yang telah dirumuskan yaitu ada pengaruh model pembelajaran mind mapping terhadap keterampilan menulis makalah pada MKU Bahasa Indonesia 
atau Hipotesis Ha diterima kebenarannya.

\section{PEMBAHASAN}

Pengumpulan data berupa hasil kemampuan menulis karangan argumentasi mahasiswa di lapangan yang mulai dilakukan mulai tanggal 16 September-11 Januari 2019. Selanjutnya, tes awal dan tes akhir menulis makalah dilakukan terhadap mahasiswa semester Ir. Sebelum dilakukan tes akhir, mahasiswa diberi pembelajaran menulis makalah sebagai latihan sebanyak dua kali pertemuan. Tes awal dan tes akhir ini dianalisis untuk menguji hipotesis penelitian yang telah ditetapkan.

Uji normalitas yang dilakukan pada skor tes awal menulis makalah. Hasil uji normalitas secara keseluruhan menunjukkan bahwa data bersifat normal. Kemampuan berpikir kritis mahasiswa di atas taraf signifikansi 0,05 yaitu pada taraf 0,53 . Begitu pula dengan kemampuan menulis makalah yang berada di atas 0,05 yaitu 0,43 .

Berdasarkan hasil uji T yang dilakukan terhadap model pembelajaran mind mapping dan kemampuan menulis makalah mahasiswa, dapat disimpulkan bahwa mind mapping memiliki pengaruh yang positif. Untuk menyimpulkan hal tersebut, pertama-tama dilakukan analisis terhadap hasil pretes-postes menulis makalah. Analisis ini menghasilkan kesimpulan bahwa terdapat peningkatan yang signifikan dari skor pretes ke skor posttest. Hal ini dilakukan untuk melihat seberapa besar perbedaan kenaikan yang dialami oleh mahasiswa saat pretest dan postest. Hasil yang diperoleh adalah 0,025. Dengan memperhatikan kriteria pengujian, yaitu nilai signifikan $<0,05$ maka disimpulkan bahwa penggunaan model pembelajaran mind mapping memiliki pengaruh pada kemampuan menulis makalah mahasiswa pada MKU Bahasa Indonesia. 


\section{DAFTAR PUSTAKA}

Alek dan Ahmad. (2010). Bahasa Indonesia untuk Perguruan Tinggi. Jakarta: Kencana.

Armariena, D. N. (2015). Pengaruh Strategi Herringbone dan Kemampuan Berpikir Kritis terhadap Kemampuan Menulis Karangan Argumentasi Siswa Kelas VII SMP Negeri 45 Palembang. Jurnal Dosen Universitas PGRI Palembang.

Armariena, D. N. (2017). Penulisan Narasi Mahasiswa dengan Metode Copy teh Master dalam Menghidupkan Kartakter, Perilaku dan Konflik Tokoh. Prosiding Dosen Universitas PGRI Palembang Edisi 9, 10-19. Palembang: Universitas PGRI Palembang.

Jacobs, H. L., dkk. (1981). English Composition Program Testing ESL Compsition: a Practical Approach. London: Newbury House Publisher Inc.

Kellog, Ronald T. (2008). Training Writing Skills: A Cognitive Developmental Perspective Journal of Writing Research. USA: Department of Psychology, Saint Louis University.

Sevilla, Consuelo dkk. (1993). Pengantar Metode Penelitian. Jakarta: UI-Press.

Suparno dan Yunus M. (2009) Keterampilan Dasar Menulis. Jakarta: Universitas Terbuka.

Tarigan, H. G. (2008). Menulis: Sebagai Suatu Keterampilan Berbahasa. Bandung: Angkasa. 